\title{
Values of Character Education on Children's Poetry by Turiyo Ragilputra
}

\author{
Tri Mulyono, ${ }^{1, *}$, Sukini Sukini², Basukiyatno Basukiyatno ${ }^{1}$
}

\author{
${ }^{1}$ Universitas Pancasakti Tegal, Indonesia \\ ${ }^{2}$ Universitas Widya Dharma Klaten, Indonesia \\ Corresponding author. Email: upstrimulyono@gmail.com
}

\begin{abstract}
This paper intends to describe the Indonesian children's poetry character education values written by Turiyo Ragilputra. The objects of this research are Indonesian children's poems by Turiyo Ragilputra in Surat dari Samudra, Agus Budi Wahyudi, et al, Central Java Language Center, 2018. Qualitative descriptive was employed as the method of conducting the research of this paper. The data are collected by doing literature study. Data analysis is carried out using hermeneutic rules. Findings show that the character education values laid in Turiyo Ragilputra's poems are religious, peace-loving, social care, environmental care, and friendship.
\end{abstract}

Keywords: The Value of Education, Character Education, Children's Poetry

\section{INTRODUCTION}

Poetry as a literary work is written not only to entertain but also to educate. In his book entitled Kajian Sastra Anak, Winarni quotes Santosa's opinion that there are two functions of children's literature [1], namely educating and entertaining [2]. Children's literature serves to educate as it presents a lot of information about something, for example providing knowledge, training skills, and presenting examples of moral lessons. Children's literature is to entertain because it is deliberately written to entertain, for example entertaining because of the beauty of the language, the attractiveness of the paintings so that it fascinates the readers. Therefore, a collection of poems entitled Surat dari Samudra was written to provide character education materials for elementary school (SD) children [3]. If the collection of children's poems is written for the purpose of character education, there raises a question, "Are there character education values in it?

According to Ratna Megawangi as quoted by Kesuma, et al character education is realized by any efforts to provide education for enabling students making the right decisions, for example, always behave / do positive actions so that they can be useful for the communities in their respective neighborhoods [4]. The positive attitude or behavior referred to what the National
Education Ministry states, namely religious attitudes, honesty, tolerance, discipline, hard work, creative, independent, democratic, curiosity, national spirit, patriotism, achievements respect, friendly/communicative, peace-loving, reading habit, environmental care, social care, and being responsible.

Another understanding of character education is put forward by Suyanto, Asmani that character education is supposed to have positive aspects to be practiced [5]. The point is that in character education there has to be aspects of knowledge (cognitive), feelings, and action which Thomas Lickona categorizes as three prominent character education aspects [6]. The inculcation of character education values according to $M$. Noor is very effective when carried out with the media of literary works, especially children's literature or children's poetry [7]. It happens because the internalization process takes place naturally and is far from dictating or patronizing.

Wibowo explains that the term 'character' is from Greek word meaning 'to mark' [8]. It marks someone's behavior. Literally according to Hornby and Parnwell, character means mental or moral quality, it can also mean moral strength [9]. In the 
Dictionary of Psychology, Dali Gulo say it is stated that character is personality from an ethical or moral point of view such as one's honesty [10].

\subsection{Poetry and Character Education Values}

Children's poetry is poetry written by paying attention to aspects of the child's mental development as potential readers. Perrine states that poetry is "universal as language and almost as ancient" [11]. Poetry according to Sudjiman, consists of various literature whose language is beautified by aspects of sound, form, and meaning [12]. What is meant by the sound aspect is rhyme, for example. Included in forms are treason and typography or engraving of shapes. Aspects of meaning in poetry are created by using figure of speech or language style.

Shahnon Ahmad suggests that a poetry contains some properties such as emotion, imagination, thought, idea, tone, rhythm, sensory impression, word order, figurative words, density, and mixed feelings [13] . Meanwhile, Winarni suggests that the characteristics of children's poetry include (1) the content must be in accordance with the level of development of the child's soul, (2) it attracts children's attention, (3) it has the beauty of language because it contains rhythm, pressure, and games of sounds, (4) the choice of words is according to the level of development of the child's soul [2]. According to Nurgiyantoro Indonesian children's poetry in general has religious themes, teachers and parents, and environment and creatures [14].

Studies on the values of character education in Indonesian literary works have been carried out by a number of authors. The authors include Suryaman, Gularso, Hermawan and I Ketut Sudarsana, Widayati and Farida Nugrahani, Jalio Yudin, and Devilito'. Suryaman, in his article entitled "Character Education through Literary Education", argues that: (1) literature is the best media for mental and intellectual enlightenment learning to use, (2) various literary activities that can be used for character education are those that related to listening, speaking, reading, and writing, (3) the most effective literary activities for learning character education are those related to reading and writing skills, and (4) to support the learning of character education values in schools literary works in line with students' mental development is needed [15].

Gularso et al's research, found that the counselor's knowledge 'correct and clean' in teaching within the family sphere was the responsibility of the father and mother. Meanwhile, the counselor's knowledge 'beautiful' is primarily to be taught by father [16].

Herawan and I Ketut Sudarsana's research, concludes that the character education values contained in
Suddhamala geguritan are religious, tolerance, honest, peace-loving, disciplined, hard work, curiosity, respect for achievement, responsibility, creative, independent, friendly, care of social care, environmental care, and homeland love [17].

According to Widayati and Farida Nugrahani in their study, character education patriotism is found in films that are transformed from literary works [18].

Character education values correlated to giving, for example appreciation, foregiveness, knowledge, and goods according to Jalio Yudin et al (2021) is found in the novel Guru Aini by Andrea Hirata. He stated this in his article which examined kidness and responsibility in character education practiced in the relationship between teacher and students in Andrea Hirata's Guru Aini [19].

Meanwhile, Rio Devilito, et al, in their article "Character Education Through Depiction of Life in the Novel Entitled" suggests that character education values contained in novel Entitled is suitable to be taught to students through the characters' of the main characters [20].

From a number of articles previously discussed, it is known that character education values have been investigated by a number of experts, it is known that research on character education in poetry, especially Indonesian children's poetry by Turiyo Ragilputra has never been done by other researchers. Therefore, the authors conducted this research to describe the values of character education in Indonesian children's poetry by Turiyo Ragilputra in Surat dari Samudra, a compilation of poetry by the best writers from Central Java [2]. The poems in Surat dari Samudra are designated as supporting materials for elementary Indonesian language and literature subject so as to motivate writers to observe the values of character education, especially in Turiyo Ragilputra's poems.

\section{METHODOLOGY}

This research was conducted using descriptive analytic and hermeneutic methods. Analytical and hermeneutic descriptive methods are carried out by describing the facts followed by hermeneutical analysis and interpretation. The object of the research is the children's poems by Turiyo Ragilputra which are published in the collection of children's poems Surat dari Samudra [2]. Data were collected by doing literature study, namely by reviewing library materials such as books, seminar papers, and articles published in journals. The data analysis was carried out using heuristic and 
hermeneutic rules. Heuristic rules are used to interpret poetry denotatively; while hermeneutic rules are used to analyze poetry with connotative meanings considering that poetry is an imaginative work.

\section{RESULTS}

Findings indicate that character education values exist in Indonesian children's poems by Turiyo Ragilputra in the collection of children's poems Surat dari Samudra concerns with the value of character education of religious, peace-loving, social care, care for the environment, and friendship.

\subsection{Religious}

Religious character education value is realized in the poems entitled "Bunga untuk Tuhan", "Lihatlah Lambaian Tanganku, Tuhan", "Di Bawah Payung", "Mulut Kuda", and "Adikku". In the poem entitled "Bunga untuk Tuhan", the value of religious can be seen in the second verse as shown in the following piece of work.

\section{Bunga untuk Tuhan}

$$
\cdots
$$

Kunikmati hidup dengan ceria

Penuh syukur atas karunia

Tuhan Yang Maha Pemurah

Maha Pengasih dan bijaksana

atas rahmat yang dilimpahkan

ilmu, kasih sayang bunda,

rasa tenteram, dan kesehatan

(Wahyudi, pp. 283).

Religiosity can be seen in obedience in teaching religious things, tolerance of other religions practice of worship, and peaceful life with adherents of other religions. Obedient behavior in carrying out religious teachings that show religious values is to always be grateful for God's gifts because they are blessed with knowledge, mother's love, a sense of peace, and health, as shown in the passage of the poem above.

Similarly, religiosity is also owned by the poem entitled "Beribadah kepada Tuhan". In the poem, the value can be seen in the first stanza which consists of five lines. Here they are.

\section{Beribadah kepada Tuhan}

Beribadah kepada Tuhan ibarat petani menanam bibit tanaman

semua yang ditanam benih pilihan

agar suatu saat nanti

memetik hasil buah kebaikan

(Wahyudi, pp. 284).

In Islamic education sources, it is stated that the jinn and humans are not created except for worship. What is meant by worship here is to carry out all God's commands and leave God's inhibitions. In the poem entitled "Beribadah kepada Tuhan", the task of human in life is like a farmer grows seeds. The seeds that are planted are the best choice of seeds, namely planting goodness (seeds of choice) so that the farmer obtains good results / happiness of future life.

The religious value in the poem entitled "Lihatlah Lambaian Tanganku, Tuhan" is found in the fourth stanza. It shows as follows.

\section{Lihatlah Lambaian Tanganku, Tuhan}

$$
\begin{aligned}
& \text { Biarkan kami yang berwarna-wami } \\
& \text { melangkah bersama dalam perbedaan } \\
& \text { menghias indah kehidupan ini } \\
& \text { melestarikan warna pelangi dalam } \\
& \text { kebersamaan }
\end{aligned}
$$

(Wahyudi, pp. 285).

The quote above describes the obedient attitude and behavior in carrying out the religious teachings adopted by God's creations. God gives every human being the freedom to be good, because everything is like growing plants, there will be a reward equitable with the action.

The first stanza of the poem entitled "Di Bawah Payung" states that life is a long and winding journey but people must pass it because everything is their natural tendency. What is meant by the journey here is the inner journey of human being towards the Creator, the God Almighty. In Islamic poetry, the journey is often described as a trip up a mountain, riding on a horse, a trip on the sea, or riding a bird to the sky. In the poem entitled "Di Bawah Payung", the journey is described in the first verse as follows.

\section{Di Bawah Payung}

Hidup adalah sebuah perjalanan 
panjang, berkiku, dan banyak tantangan

tetapi harus dilalui

karena hidup adalah fitrah

sebelum akhirnya Kembali

menghadap Tuhan Ilahi Rabi

(Wahyudi, pp. 286).

In the poem entitled "Mulut Kuda", religiosity as a part of character education value can be recognized in the second verse. It explains that the mouth is a gift from God. God asks people to use their mouths for good things, namely to pray, make remembrance, convey goodness and increase piety. The following is a quote from the second stanza.

\section{Mulut Kuda}

Mulut adalah anugerah Tuhan

Tak dijual di warung, pasar, kios,

Atau toko swalayan

Tuhan memberikan secara cuma-cuma

Dari kita Tuhan tak menuntut satu apa

Tuhan hanya memerintahkan

Menggunakan mulut untuk berdoa

Berzikir dan bicara utama

Tentang kebaikan dan kesalahan

(Wahyudi, pp. 287).

Meanwhile, in the poem entitled "Adikku", character education of religious appears in the forth verse, which conveys the teachings of sincerity. The following quote shows that.

\section{Adikku}

Adikku, janganlah

Janganlah, Adikku

Biarlah ibu tenang di sana

Menjadi tamu terhormat Tuhan Yang Kuasa

Duduk berdampingan dengan orang-orang tercinta

Para nabi

Para wali

Serta orang-orang terpilih yang hidup

Di alam sunyi

(Wahyudi, pp. 292)
The quote says that every living thing will surely die. Therefore, family members who are still alive should let the dead go, not continue to bemoan and regret the death of those closest to them. Children should let their dead parents go. A parent also has to let go if his child has to return to God.

\subsection{Loving-peace}

In addition to the religious value, the Indonesian children's poems by Turiyo Ragilputra also contain a peace-loving value. It is found in the poem entitled "Surat untuk Bu Guru". The poem consists of four stanzas and its character education value can be observed in the fourth verse as follows.

\section{Surat untuk Bu Guru}

Bu guru
kami lebih senang jika bu guru
menyapa kami dengan bahasa hati nurani
dengan sapaan menyentuh hati
"Selamat pagi, anak-anak"
Yang akan kami jawab
"Selamat pagi, Bu Guru"
Daripada hai halo, halo hai
tegur sapa yang merusak kelembutan hati
tegur sapa bergaya koboi

(Wahyudi, pp. 288).

Peace-loving is an orientation, action, and expression that influence others or partners feel comfortable in his existence. In the poem above it is described that students do not like when the teacher greets them by saying hi or hello to them (students). The students claims that they prefer the teacher saying "Good morning" and they will reply "Good morning, Ma'am/Sir". The greeting is considered more soothing and reflects the softness of the speaker's heart than other greetings, such as 'hi/hello'.

\subsection{Social Care}

Social care value of character education in Turiyo Ragilputra's poems is found in the poem entitled "Ki Dalang". It is found, among others, in the second verse, as can be read in the following quote. 


\section{Ki Dalang}

Ki dalang

Kau hibur penonton dengan cerita jenaka

Kau wejang pemirsa dengan pesan-pesan utama

Tentang segala ulah manusia

Pergulatan antara kebajikan dan durhaka

Agar dipelajari dan diselami

Demi lestari dan damainya jagat raya ini

(Wahyudi, pp. 298).

Attitudes and actions that always care/pay attention to the community or other people who need help are called social care characters. The provision of assistance/help is not always in the form of material and material possessions, it can also be in the form of advices to do good or amuse people. As can be seen in the quote above, $\mathrm{Ki}$ Dalang provides entertainment as well as advices/suggestions to the audience of the puppet performances. The advice is conveyed indirectly through the puppets that show that human deeds are diverse and complex, some are bad/evil, some are good and noble. The audience must be able to evaluate those actions. In dealing with disputes/feuds between good and bad, people should always prioritize virtue for the realization of a safe and peaceful life.

\subsection{Care for the environment}

Environmental care value of character education in Turiyo's poems is found in the poem entitled "Bengawan Solo". In the poem which consists of four stanzas, the environmental care is recognizable, among others, in the fourth verse which consists of nine lines. The following quote shows that.

\section{Bengawan Solo}

$\cdots$

Bengawan Solo

Menatap wajahmu penuh luka

Jiwaku tercabik

Jiwaku mengerang

Jiwaku tercekik

Jiwaku meradang!

Bengawan Solo, kaulah saksi

Tentang keprihatinan yang terabaikan
Tentang kelestarian yang dikorbankan

(Wahyudi, pp.u 294).

I $\mathrm{n}$ the quote, the poet's sense of environmental concern can be seen in the repetition of the word "my soul" up to four times in the third, fourth, fifth, and sixth lines. Why did the poet's soul feel torn, groaned, suffocated, and inflamed? Because he noticed the fact that the sustainability of the Bengawan Solo is neglected. We know that environmental care is an orientation and movement to preserve and improve environment condition. The poem deeply concerns about the condition because people around Bengawan Solo are considered to be lacking of efforts in the environmental preservation, namely the river flow so that the poet sees red. For the sake of a safe, serene, peaceful and prosperous life, people must care about the environment.

\subsection{Friendly/Communicative}

Friendly/communicative character education in Turiyo's poems is found in the poem entitled "Jamuran". In the poem, it is observable in the third verse as follows.

\section{Jamuran}

\author{
Dalam permainan, dalam kehidupan \\ yang kalah jangan disisihkan \\ yang menang jangan sewenang-wenang \\ sebab kalah dan menang \\ adalah pasangan yang serasi \\ pasangan kekal abadi
}

(Wahyudi, pp. 290).

In the quote it is written that //In the game, in life/the loser should not be excluded/the winner should not be arbitrary/because losing and winning/are a perfect match/.../. This shows character education value of friendliness because the aim of the game is to establish friendly relations, not to cause hostility. Friendly character is an initiation that reflects a sense of happiness in talking, socializing, and cooperating with other. Therefore, those who lose in the game should not be set aside, those who win must not be arrogant. Wins and loses always happen in the game so it should be enjoyed with pleasure and the players must 
maintain harmonious relations between each other, friendly and communicative.

\section{DISCUSSION}

It has been stated earlier that the character education values found in Indonesian children's poems by Turiyo Ragilputra are religious, peace-loving, social care, environmental care, and friendly. Religiosity in character education value is owned by six poetry titles, namely "Bunga untuk Tuhan", "Beribadah kepada Tuhan", "Lihatlah Lambaian Tanganku, Tuhan", "Di Bawah Payung", "Mulut Kuda", dan "Adikku". In the collection of poems Surat dari Samudra, Turiyo Ragilputra wrote 10 titles of poems and six of them depict the religious value of character education. It is obvious because religious value becomes the most significant value among others. It appears that this value is always prioritized in discussing character education values. Therefore, it is not surprising to know the religious value is also found in every analysis of character education values in literary works.

Findings of Ni Luh Lina Agustina Dewi's research on the novel Sepatu Dahlan by Khrisma Pabichava imply that this literary work has a religious value. Likewise, the results of research by Kadek Dedy Herawati and I Ketut Sudarsono on Suddhamala's geguritan. In addition, the results of Khidmatul Mamluah's research on Indonesian novels with the main character Dahlan Iskan also found the value of character education of religious. Even though character education is commonly found in the analysis of pieces of writing, findings regarding the value of character education of religious in children's poetry by Turiyo Ragilputra is something new because research on religious character education in Indonesian children's poetry has never been done by other researchers.

Peace-loving is an attitude, expression, and action that make the readers or listeners feel happy and comfortable. In a children's poem by Turiyo Ragilputra, the character of peace-loving is found in the poem "Surat untuk $\mathrm{Bu}$ Guru". Peace-loving was not found in Khidmatul Ableah's research and neither was found in Agustina Dewi's. The value of character education of peace-loving was found by Dedy Herawan and I Ketut Sudarsana in their research on Suddhamala's geguritan. It implies that the peace-loving value is found in poems, not in novels. Paying attention to Nurgiyantoro's statement in his book Children's Literature which states that the theme of children's poetry includes religion, teachers and parents, and natural environment and creatures, the finding that in Turiyo Ragilputra's children poetry there is a value of character education of peaceloving can be considered as a new finding in Indonesian children's poetry literature. Likewise, the findings regarding the description of social care in Indonesian children's poetry by Turiyo Ragilputra conveyed through the speech of ki dalang when playing wayang characters - are also new findings.

In addition to the values of character education of religious, peace-loving, and social care, in the poems of Turiyo Ragilputra also found the value of environmental concern. Concern for the environment in Turiyo Ragilputra's poem is especially found in the poem entitled "Bengawan Solo" which indirectly invites people to pay attention to the environment sustainability so that life becomes safe, serene, peaceful, prosperous, without disturbances that threaten the safety of human life.

\section{CONCLUSION}

According to the analysis, of Turiyo Ragilputra's Surat dari Samudra: Antologi Puisi Anak by Wahyudi, et al. several values of character education are found, namely: (1) the value of religious in character education, peace-loving, social care, environmental care, and friendly, (2) the findings of the peace-loving values and socialcaring character education in children's poetry by Turiyo Ragilputra can be considered as new findings.

\section{REFERENCES}

[1] Puji Santoso, Pengetahuan dan Apresiasi Sastra dalam Tanya Jawab, Nusa Indah, Ende-Flores, 1986.

[2] Retno Winarni, Kajian Sastra Anak. Graha Ilmu, ISBN: 978-978-1098-12-4, Yogyakarta, pp. 4-5, 2014

[3] Agus Budi Wahyudi et. al., Surat dari Samudra: Antologi Puisi Anak, Balai Bahasa Jawa tengah, ISBN: 978-602-52389-9-4, Semarang, 2018.

[4] Dharma Kesuma, Cepi Triatna, and Johar Permana, Pendidikan Karakter Kajian Teori dan Praktik di Sekolah, Rosda Karya, ISBN: 978-979-692-044-0, Bandung, pp 5, 2012.

[5] Jamal Ma'mur Asmani, Buku Panduan Internalisasi Pendidikan Karakter di Sekolah, DIVA Press, ISBN: 978-602-978-843-9, Jogjakarta, pp 31, 2013. 
[6] Thomas Lickona, Educating forCharacter: Mendidik untuk Membentuk Karakter (Terj. Juma Abdu Wamaungo). Bumi Aksara, Jakarta, 2012.

[7] Rohinas M. Noor, Pendidikan Karakter Berbasis Sastra Solusi Pendidikan Moral yang Efektif, ArRuzz, ISBN: 978-979-25-4857-0, Jogjakarta, pp 37, 2011.

[8] Agus Wibowo, Pendidikan Karakter Berbasis Sastra. Pustaka Pelajar, ISBN: 978-602-229-222-7, Yogyakarta, pp 11, 2013.

[9] A.S. Hornby and E.C. Parnwell, Learner's Dictionary. Kualalumpur: Oxford University Press, pp 49, 1972.

[10] Dali Gulo, Kamus Psikologi. Bandung: Tonis, pp 29, 1982.

[11] Laurence Perrine, Literature: Structure, Sound, and Sense, Harcourt, Brace, and World, Inc, ISBN: 015-551100-9, New York, pp 515, 1970.

[12] Panuti Sudjiman, Kamus Istilah Sastra. Gramedia, ISBN: -, Jakarta, pp 61, 1986.

[13] Shahnon Ahmad, Penglibatan dalam Puisi, Kuala Lumpur: UtusanPublication \& Distributors SDN. BHD, 1978

[14] Burhan Nurgiyantoro, Sastra Anak. Yogyakarta: Gadjah Mada University Press, ISBN: 979-420598-2, Yogyakarta, 2005.

[15] Maman Suryaman, "Pendidikan Karakter Melalui Pendidikan Sastra," Cakrawala Pendidikan, Tahun XXIX, Mei 2010.
[16] Dhiniaty Gularso, Sugitu, and Zamroni, "Kawruh Pamomong: Children Education Based on Local Wisdom in Yogyakarta," Cakrawala Pendidikan, vol. 38, no. 2, June 2019, pp. 343-355.

[17] Kadek Dedy Herawan and I Ketutu Sudarsana, "Relevansi Nilai Pendidikan Karakter dalam Geguritan Suddhamala untuk Meningkatkan Mutu Pendidikan di Indonesia," Jurnal Penjamin Mutu Lembaga Penjamin Mutu Institut Hindu Dharma Negeri Denpasar, vol. 3, no. 2, August 2017.

[18] Mukti Widayati and Farida Nugrahani, "The Character Education on Film of Literature Literary Transformation Result and Its Implementation in Learning at School," Proceeding of the International Conference on Literature: "Literature as a Source of Wisdom, ” July 2019, pp. 11-13.

[19] Jalio Yudin, Suyitno, and Muhammad Rohmadi, "The Value of Kidness and Responsibility Character Education in Theacher-Student Relationshios in the Novel of Guru Aini by Andria Herata," International Journal of Multikultural and Multireligious Understanding, vol. 8, no. 2, December 2021, pp. 108-115.

[20] Rio Devilito, Nugraheni Eko Wardani, and Kundaru Saddhono, "Character Education Through Depiction of Life in the Novel Entitled'. Jurnal Lingua Didaktika, vol. II, no. 2, Desember 2017. 